\title{
Pengetahuan dan Pemahaman Guru-guru Pendidikan Islam Anak Usia Dini (PIAUD) terhadap Literasi Kritis di Indonesia
}

\author{
Raden Aulia Utami Hidayat ${ }^{1}$, Paridah Hidayat ${ }^{2}$, Siti Umayah ${ }^{3}$ \\ 1,2Sekolah Tinggi Agama Islam Siliwangi Garut, Indonesia \\ ${ }^{3}$ Sekolah Tinggi Ilmu Tarbiyah Tanggamus, Indonesia \\ rauliastaisgarut@gmail.com
}

\begin{abstract}
Abstrak
Istilah literasi kritis cenderung dianggap sebagai sesuatu yang baru di Indonesia. Sebagian besar guru memiliki pengetahuan dan pemahaman yang terbatas tentang literasi kritis, tentang apa dan mengapa itu penting. Kesulitannya tidak hanya dialami oleh guru yang mengajar dalam pendidikan tinggi, bahkan guru pengajar anak usia dini pun merasa bahwa mereka tidak mengerti istilah ini. Penelitian ini menggunakan jenis penelitian kualitatif yang bertujuan untuk mencari tahu pengetahuan dan pemahaman gugru-guru Pendidikan Islam Anak Usia Dini (PIAUD) terhadap Literasi Kritis. Partisipan dari penelitian ini adalah lima puluh tujuh guru PIAUD di Garut, Provinsi Jawa Barat, Indonesia, yang disurvei menggunakan kuisioner daring terkait dengan pengetahuan dan pemahaman mereka tentang literasi kritis. Hasil dari kuesioner terbuka yang dianalisis secara induktif mengungkapkan bahwa, meskipun guru PIAUD ini telah mengajar selama kurang dari satu hingga lima belas tahun, mereka memahami apa itu melek huruf dan apa yang penting dalam konteks tradisional. Namun, semuanya menunjukkan kurangnya pengetahuan dan pemahaman tentang istilah literasi kritis. Disisi lain beberapa guru PIAUD menunjukkan keyakinan positif mereka pada promosi literasi kritis kepada siswa mereka dan beberapa dari mereka masih tidak yakin tentang implementasi hal yang baru tersebut karena mereka memiliki pengetahuan dan pemahaman yang terbatas tentang istilah literasi kritis tersebut.
\end{abstract}

Kata kunci: literasi kritis; anak usia dini; pemahaman guru; keyakinan guru

\section{Young Learners Teachers' Knowledge and Understanding of Critical Literacy in Indonesia Context}

\begin{abstract}
The term critical literacy tends to be considered as something new in Indonesia. Most teachers have limited knowledge and understanding of critical literacy, what and why it is important. The difficulty is not only experienced by teachers who teach in higher education, even early childhood teachers feel that they do not understand this term. This study uses a qualitative type of research that aims to find out the knowledge and understanding of early childhood Islamic education (PIAUD) teachers on Critical Literacy. The participants of this study were fifty-seven PIAUD teachers in Garut, West Java Province, Indonesia, who were surveyed using an online questionnaire related to their knowledge and understanding of critical literacy. The results of an inductively analyzed open questionnaire revealed that, although these PIAUD teachers had been teaching for less than one to fifteen years, they understood what literacy was and what was important in a traditional context. However, all of them indicate a lack of knowledge and understanding of the term critical literacy. On the other hand, some PIAUD teachers showed their positive belief in the promotion of critical literacy to their students and some of them were still unsure about the implementation of the new thing because they had limited knowledge and understanding of the term critical literacy.

Keywords: critical literacy; young learners; teachers' understanding; teachers' knowledge
\end{abstract}




\section{PENDAHULUAN}

Pada abad 21, teknologi telah berkembang pesat dan menyebabkan akses informasi yang tidak terbatas di seluruh dunia. Selain itu, gerakan literasi saat ini sedang digalakkan oleh pemerintah untuk meningkatkan angka literasi di Indonesia. Perkembangan ini menuntut guru untuk membekali siswa dengan pentingnya bersikap kritis dalam memahami informasi (Coffey, 2010; Lewison et al., 2002). Menyikapi hal tersebut, kesadaran literasi kritis harus diterapkan di setiap jenjang sekolah, untuk mengembangkan kemampuan siswa membaca melalui sikap kritis dan mengkonstruksi ide-ide kritis. Senada dengan hal tersebut, Alwasilah (2001) menyatakan bahwa untuk mengembangkan literasi kritis siswa, sebagai media untuk meminimalisir permasalahan sosial, pendidikan harus dimanfaatkan.

Penerapan literasi kritis seharusnya tidak hanya difokuskan pada pendidikan tinggi tetapi juga pada pendidikan anak usia dini karena para anak usia dini tumbuh di era teknologi yang tentunya dipengaruhi oleh modernisasi teknologi dan peradaban manusia. Penerapan literasi kritis akan mendorong siswa anak usia dini untuk aktif menganalisis teks dan berpikir kritis tetapi juga memungkinkan siswa untuk menghasilkan dan merancang cara untuk mengatasi atau memecahkan masalah (Alwasilah, 2001). Mahasiswa tidak hanya menjadi konsumen pasif dalam menerima informasi tetapi juga dapat aktif dan kritis. Literasi kritis diharapkan dapat menjadi metode yang efektif untuk menjadikan siswa menjadi generasi literasi kritis yang mampu menghadapi dan menantang modernisasi informasi dan teknologi.

Namun, dalam menerapkan literasi kritis kepada siswa, ada baiknya untuk mengetahui keyakinan dan pemahaman guru terhadap siswa tentang literasi kritis itu sendiri. Senada dengan hal tersebut, Gustine (2018) dan Hidayat (2020) menemukan bahwa sebagian besar guru masih bingung dengan apa itu literasi kritis dan bagaimana menciptakan dan kelas kritis. Padahal dalam menyelenggarakan kelas berbasis kritis, titik tolaknya adalah guru yang harus melek kritis untuk membekali siswa agar kritis (McDaniel, 2006). Apalagi untuk mewujudkan bangsa yang cerdas dan berbudaya, literasi kritis harus diterapkan sedini mungkin sebagai 'aset' utama. Oleh karena itu, guru anak usia dini harus memiliki keyakinan dan pemahaman yang tepat tentang literasi kritis sebelum mereka menerapkannya di kelas mereka. 
Berdasarkan penjelasan di atas, ada kebutuhan yang cukup mendesak untuk menyelidiki keyakinan dan pemahaman guru tentang literasi kritis ini. Penelitian ini juga mencoba untuk menemukan harapan yang bisa guru kaitkan tentang bagaimana mereka dapat mengembangkan kelas berbasis literasi kritis. Untuk mencapai tujuan tersebut, ada dua pertanyaan penelitian yang terkait dengan penelitian ini yaitu mengenai apa arti literasi kritis bagi guru PIAUD dan bagaimana keyakinan mereka tentang literasi kritis.

Sebagai permulaan, istilah literasi kritis atau Critical Literacy perlu didefinisikan terlebih dahulu. Secara tradisional, kata "kritis" mengacu pada kemampuan menilai dan berdebat (Luke \& Woods, 2009), sedangkan istilah 'literasi' didefinisikan sebagai kemampuan membaca dan menulis (Kalantzis \& Cope, 2012). Dalam penelitian ini, literasi kritis didefinisikan sebagai sikap, cara berinteraksi dengan dunia, cara hidup, cara berpikir, dan seperangkat keterampilan dan strategi mengajar pada tingkat yang berbeda (McDaniel, 2006). Lebih lanjut Janks (2010) dan Hood (1998) menyatakan bahwa literasi kritis adalah filosofi yang mengidentifikasi hubungan antara bahasa, kekuasaan, dan pengetahuan serta bagaimana bahasa digunakan untuk mendukung dominasi. Dengan demikian, literasi kritis sering dikaitkan dengan tindakan untuk menciptakan masyarakat yang adil secara sosial di tingkat kolektif. Selanjutnya, literasi kritis dipandang sebagai bentuk kemampuan literasi dalam membuat kontradiksi dan refleksi dari informasi yang diberikan dalam teks. Kesadaran literasi kritis menekankan fakta bahwa teks dapat dikonstruksi untuk memahami latar belakang dan pilihan yang dibuat oleh penulis(Janks, 2010). Dari rangkaian definisi diatas, dapat disimpulkan bahwa literasi kritis merupakan keterampilan berbahasa dan bersosial yang penting untuk dikuasai oleh guru dan murid.

Literasi kritis memberikan banyak kepentingan bagi guru dan siswa, terutama dalam mengembangkan kesadaran sosial mereka. Literasi kritis cocok untuk mempromosikan tindakan untuk keadilan social (Norris et al., 2012). Senada dengan hal tersebut, Park (2012) dan Peterson dan Chamberlain (2015). menemukan bahwa penerapan literasi kritis dapat mendukung siswa untuk menyadari orang lain, masyarakat, kekuasaan, budaya, dan terutama teks itu sendiri. Hal ini juga didukung oleh (Luke \& Woods, 2009) yang menemukan bahwa anak-anak menjadi lebih sadar sosial dan secara interaktif merespon banyak ide melalui penerapan literasi kritis di kelas. 
Berfokus pada keterampilan literasi kritis akan memberikan kemampuan siswa untuk mengetahui identitas dan lingkungan mereka karena siswa sebagai generasi milenial akan terpengaruh oleh modernisasi di mana berita dan isu-isu lainnya terus menyebar dari berbagai sumber di seluruh dunia. Oleh karenanya, pengetahuan dan pemahaman akan pentingnya literasi kritis ssangatlah dibutuhkan saat ini.

Siswa yang terlibat dalam literasi kritis akan memahami bahwa informasi yang disajikan dalam teks, majalah, surat kabar, lirik lagu, dan situs web telah ditulis dari perspektif tertentu untuk tujuan tertentu (Lewison et al., 2002). Melalui penerapan literasi kritis, siswa dan guru dapat mengeksplorasi dan memahami serta menghargai persamaan dan perbedaan yang mereka miliki dan membagikannya (Koo et al., 2012). Selain itu, siswa juga akan menjadi lebih bijak dalam menanggapi segala informasi karena akan selalu memikirkan beberapa aspek penting yang hanya akan didapatkan dan dipahami melalui pengimplementasian literasi kritis di sekolah. Begitu pula bagi anak usia dini, kelak di masa depan, ketika mereka sudah terbiasa mengaplikasikan literasi kritis sejak dini, mereka akan menjadi generasi yang mampu bersikap adil dan bijaksana dalam masyarakat mereka nanti. Namun, dalam penerapannya tentu terdapat beberapa tantangan dalam menerapkan literasi kritis.

Bagian ini mengkaji beberapa tantangan dalam menerapkan literasi kritis di kelas. Menurut Kaur dan Sidhu (2014) dan Bacon (2017), literasi kritis melibatkan perspektif siswa yang beragam dan saling bertentangan yang sulit untuk dipraktikkan. Kalantzis dan Cope (2012) menemukan bahwa sebagian besar guru masih ragu-ragu tentang bagaimana menciptakan ruang kelas yang kritis dan bagaimana membantu siswa menjadi kritis. Selain itu, penelitian yang dilakukan oleh Norris et al. (2012) mengusulkan bahwa untuk melakukan kelas berbasis kritis, guru harus menjadi kritis melek untuk memberikan siswa ruang untuk menjadi kritis. Selanjutnya, dalam hal kesulitan siswa, Park (2012) menemukan bahwa perubahan dari kelas tradisional ke kelas kritis dianggap sulit tidak hanya bagi siswa tetapi juga bagi guru untuk diwujudkan. Lebih lanjut, Bacon (2017) menemukan bahwa banyak siswa merasa sulit untuk memahami teks kritis dan mereka ingin diberikan pelatihan literasi kritis. Lee (2012) dan Falkenstein (2003) keduanya menemukan bahwa beberapa peserta mereka menolak penerapan literasi kritis karena mereka menemukan beberapa keyakinan, interpretasi, budaya, dan ideologi yang berbeda di dalam teks. Selain itu, dalam persepsi 
siswa, Park (2012) dan Lee (2012) menyatakan bahwa penerapan literasi kritis dapat mendorong siswa untuk menyadari orang lain, masyarakat, kekuasaan, budaya, dan terutama teks itu sendiri. Hal ini didukung oleh Luke dan Woods (2009) yang menemukan bahwa anak-anak menjadi lebih sadar sosial dan secara interaktif merespon banyak ide melalui penerapan literasi kritis di kelas.

Kurangnya penelitian tentang keaksaraan kritis dalam pengaturan EFL sebagian besar terkait dengan kurangnya kepercayaan guru dalam kapasitas siswa dan pengetahuan guru tentang literasi kritis (Kalantzis \& Cope, 2012). Penelitian dalam ranah pendidikan anak usia dini terutama di konteks negara kita masihlah minim. Sehingga, penelitian ini diharapkan dapat memperkaya koleksi literatur tentang keyakinan dan pengetahuan guru tentang literasi kritis dalam konteks EFL dan menemukan harapan guru untuk mengembangkan kelas yang berorientasi literasi kritis.

Ada beberapa penelitian terkait penerapan literasi kritis dalam konteks pendidikan anak usia dini. Studi percaya bahwa penerapan literasi kritis untuk pelajar anak usia dini dapat melibatkan anak usia dini dengan semua modalitas teks yang penting bagi mereka untuk menciptakan mereka sebagai warga masyarakat yang pluralistik dan demokratis. Itu juga mempersiapkan mereka untuk masa depan mereka dan partisipasi mereka di dunia yang lebih besar di sekitar mereka. Potongan penelitian penting ini juga mulai meruntuhkan beberapa asumsi tentang ketidakmampuan anak usia dini untuk terlibat dalam pembelajaran berbasis kritis (James \& McVay, 2009; Labadie et al., 2012).

\section{METODE PENELITIAN}

Untuk menyelidiki pemahaman dan pengetahuan guru Pendidikan Anak Usia Dini (PIAUD) tentang literasi kritis dalam konteks Indonesia, penelitian dengan metode kualitatif diadakan selama satu bulan mulai dari mempersiapkan pertanyaan, proses pengisian kuisioner, hingga analisis hasil kuisioner. Metode kualitatif dipilih karena penelitian ini ditujukan untuk menangkap gambaran nyata pengetahuan dan pemahaman guru berkaitan dengan literasi kritis (Fisher, 2005). Sejumlah pertanyaan dalam bentuk kuesioner online terbuka dibagikan pada para guru PIAUD. Partisipan dari penelitian ini adalah lima puluh tujuh guru PIAUD dari berbagai sekolah di Garut, Jawa Barat, Indonesia, yang telah mengajar antara satu hingga lima belas tahun. 
Berkaitan dengan kedua pertanyaan penelitian yang telah disebutkan diatas, pertanyaan-pertanyaan di dalam kuisioner dikembangkan untuk menjawab secara menyeluruh pertanyaan penelitian dalam tulisan ini. Sebelum kuesioner dibagikan, pertanyaan pada formulir online ditinjau oleh rekan-rekan saya (Fisher, 2005). Kuesioner semuanya terbuka dan terdiri dari tiga bagian utama. Bagian pertama terkait dengan pemahaman dan pengetahuan peserta tentang makna tradisional literasi dan kritis. Bagian kedua adalah pemahaman dan pengetahuan peserta tentang istilah literasi kritis. Yang ketiga adalah pemahaman dan pengetahuan peserta tentang kemungkinan keaksaraan kritis dipromosikan di kelas mereka.

Analisis induktif terhadap konten digunakan untuk menganalisis hasil kuesioner (Fisher, 2005), data dari kedua kuesioner dianalisis untuk membaginya menjadi beberapa tema yang muncul terkait dengan pemahaman dan pengetahuan guru anak usia dini tentang literasi kritis.

\section{HASIL DAN PEMBAHASAN}

\section{A. Hasil}

Bagian berikut membahas temuan dan diskusi dari kuesioner. Temuan dan diskusi dibagi menjadi dua isu utama yang berkaitan dengan dua pertanyaan penelitian. Tema pertama mengkaji pemahaman dan pengetahuan peserta tentang literasi kritis; sub-bagian kedua menyelidiki seberapa jauh pemahaman dan pengetahuan mereka tentang literasi kritis.

\section{Pengetahuan dan pemahaman guru PIAUD tentang literasi kritis}

Tema pertama dalam kuesioner terkait dengan pemahaman guru anak usia dini tentang literasi kritis dari perspektif dan pengalaman mereka sebagai guru. Sebagai permulaan, pertanyaan yang diajukan terkait untuk menanyakan pemahaman dan pengetahuan mereka tentang literasi dan kritis dalam konteks tradisional. Menanggapi pertanyaan-pertanyaan tersebut, semua peserta memahami dan memiliki pengetahuan yang cukup tentang definisi dari setiap istilah. Mereka tahu bahwa literasi secara tradisional dipandang sebagai kemampuan membaca dan menulis. Berikut adalah beberapa jawaban dari para guru PIAUD berkaitan dengan pengetahuan dan pemahaman mereka mengenai literasi secara tradisional: 
Al Athfaal: Jurnal Ilmiah Pendidikan Anak Usia Dini

"Literasi adalah kemampuan seseorang dalam mengolah dan memahami informasi saat melakukan proses membaca dan menulis."

"Istilah umum yang merujuk kepada seperangkat kemampuan dan keterampilan dalam membaca, menulis, berbicara, menghitung dan memecahkan masalah pada tingkat tertentu yang diperlukan dalam kehidupan sehari-hari.”

"Literasi adalah kemampuan individu untuk membaca, menulis, menghitung, dan memecahkan masalah atau literasi adalah kemampuan seseorang dalam berbahasa."

"Literasi adalah kemampuan seseorang dalam mengolah dan memahami informasi saat melakukan proses membaca dan menulis."

"Literasi ialah seperangkat keterampilan nyata, terutama ketrampilan dalam membaca dan menulis yang terlepas dari konteks yang mana keterampilan itu diperoleh serta siapa yang memperolehnya. Bisa juga diartikan sebagainya sumber ilmu yang sifatnya membangun imajinasi individu tersebut."

"Literasi adalah kemampuan seseorang dalam mengolah dan memahami informasi saat melakukan proses membaca dan menulis. ... Jika dulu definisi literasi adalah kemampuan membaca dan menulis. Saat ini, istilah Literasi sudah mulai digunakan dalam arti yang lebih luas."

Selanjutnya, mereka juga dapat mendefinisikan bahwa orang yang kritis adalah seseorang yang melihat segala sesuatu dari sisi yang berbeda dan dapat menganalisis dan mengevaluasi informasi yang dia dapatkan. Berikut beberapa jawaban dari mereka mengenai pengetahuan dan pemahaman terkait menjadi seseorang yang kritis:

"Menjadi seseorang yang keritis itu adalah orang yang mampu menganalisis dan dapat mengevaluasi pemikiran, bukan saja pemikiran pihak lain namun juga pemikiran diri sendiri."

"Sikap kritis adalah sikap peka terhadap peristiwa yang terjadi di sekitar lingkungan. Berfikir kritis adalah berfikir secara cerdas dengan sumber-sumber yang jelas dan logis."

"Orang kritis menyikapi masalah atau informasi dengan teliti dan mencari informasi mana yang benar mana yang salah terlebih dahulu."

"Menjadi kritis berarti mempunyai kebiasaan menganalisis dan mengevaluasi bukan saja pemikiran pihak lain namun juga pemikiran kita sendiri. ... Seorang pemikir kritis memiliki beberapa ciri yaitu: Sistematis.”

"Seseorang yang selalu reflek menanggapi pertanyaan atau kejadian yang terjadi disekitar dengan selalu memberikan pertanyaan yang kadang mungkin orang lain mengerti atau tidak 
Al Athfaal: Jurnal Ilmiah Pendidikan Anak Usia Dini

bisa menjawab dan kadang bisa memecahkan persoalan-persoalan yang orang lain tidak dapat menyelesaikannya."

"Menurut saya menjadi seorang yang kritis itu adalah kita harus mempunyai pemikiran yang baik dalam hal apapun baik itu ketika mengajarkan sesuatu pada anak, dalam hal menyampaikan pendapat atau materi dan yang lainnya."

Berdasarkan jawaban dari partisipan diatas terlihat bahwa mereka sudah megetahui informasi dasar mengenai lliterasi dan bagaimana seseorang yang kritis bertindak. Ketika pertanyaan susulan mengenai pendapat mereka mengenai pentingkah mengajarkan literasi dan mengajarkan sikap kritis pada anak usia dini ditanyakan, mereka sepakat bahwa kedua kemampuan tersebut sangatlah penting untuk diajarkan pada siswa-siswa mereka.

"Mengajarkan literasi sangat bermanfaat bagi siswa karena dapat melatih kemampuan dasar pada anak untuk membaca, menulis dan berhitung; dapat mengembangkan kemampuan berpikir kritis; dan dapat mempersiapkan anak untuk masuk dunia sekolah."

"Mengajarkan pemahaman literasi kepada anak itu bermanfaat karena dengan belajar literasi akan mampu meningkatkan kosa kata pada anak, melatih anak untuk menulis dan merangkai kata dengan benar, melatih anak untuk berfikir dan menganalisa."

"Perkembangan literasi yang baik berkolerasi dengan prestasi akademik, mempersiapkan anak untuk memasuki dunia sekolah, mengembangkan kemampuan berpikir kritis, melatih kemampuan dasar anak untuk membaca, menulis, dan menghitung."

"Mengajarkan anak untuk bersikap kritis itu penting, karena berpikir kritis merupakan pola pikir yang melibatkan proses menganalisa dan mengevaluasi suatu informasi melalui pengamatan, pengalaman dan komunikasi. Dengan berpikir kritis, anak tidak hanya menerima informasi begitu saja, melainkan dengan mempertanyakannya. Sehingga kelak bisa menilai suatu informasi dan memecahkan masalah dengan tepat dan akurat."

"Mengajarkan menjadi kritis pada anak itu sangat penting karena anak dapat mengembangkan pola piker mereka. Sehingga anak tidak begitu saja dapat menerima informasi, mereka juga dapat menilai dan menyaring suatu informasi dan menyelesaikan masalah sendiri secara tepat dan akurat."

"Mengajarkan sikap kritis sangatlah penting. Kemampuan berpikir kritis ini akan menjadi landasan penting dalam kehidupan yang bisa menentukan kesuksesan seseorang di masa depan. Pada anak-anak, kemampuan berpikir kritis akan menjadi landasan penting yang mempengaruhi cara anak berpikir di usia dewasa."

"Bukan hanya orang dewasa yang harus memiliki pemikiran kritis. Si Kecil pun nampaknya sudah perlu diajarkan sejak dini Moms untuk berpikir secara kritis. Sebab, berpikir kritis dan 
Al Athfaal: Jurnal Ilmiah Pendidikan Anak Usia Dini

kreatif merupakan salah satu ciri anak cerdas. Berpikir kritis merupakan cara agar Si Kecil tidak sekadar menjadi follower (pengikut) tanpa mengetahui tujuan dan alasan melakukan sesuatu. Pada dasarnya, jika Si Kecil memiliki rasa aman dalam berpendapat, berekspresi dan bereksplorasi, secara alamiah akan muncul pertanyaan kritis dalam benaknya. Dalam bahasa lain, supaya Si Kecil bisa berpikir kritis/kreatif orangtua harus menciptakan kondisi yang mendukung. Agar berpikir kritis ciptakan rasa aman."

Untuk pertanyaan terkait istilah literasi kritis, semua peserta tidak menunjukkan pemahaman dan pengetahuan mereka tentang apa itu literasi kritis. Meskipun dalam jawaban terkait pertanyaan "Apakah anda mengetahui istilah "Literasi Kritis?" sebanyak 68,4\% menjawab "Ya", hasil dari pertanyaan lanjutan tidak mengindikasikan mereka yang tahu dan paham betul mengenai istilah tersebut.

\section{Apakah anda mengetahui istilah "Literasi Kritis"? \\ 57 jawaban}

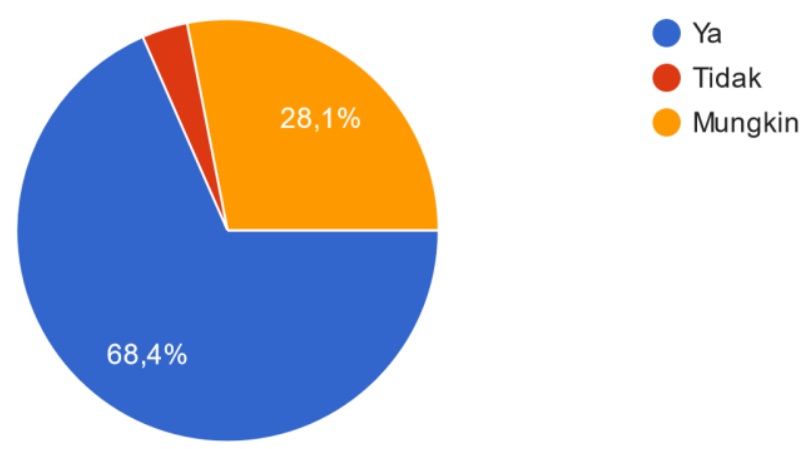

Gambar 1. Jawaban Literasi Kritis

Berdasarkan tanggapan mereka, selain menjawab "Ya" sebagian besar peserta ragu-ragu untuk menjawab pertanyaan, terlihat dari jawaban angket, mereka memilih "mungkin" pada pertanyaan tersebut. Kemudian sebagian lainnya juga menyatakan bahwa mereka tidak mengetahui apa istilah tersebut. Meski begitu, mereka semua berusaha mendefinisikan literasi kritis sesuai dengan pemahaman dan pengetahuan mereka. Berikut jawaban dari para guru PIAUD yang didapatkan dari kuisioner mengenai pengetahuan dan pemahaman mereka mengenai istilah "Literasi Kritis".

"Kemampuan membaca teks secara aktif dan reflektif dengan tujuan memperoleh pemahaman yang lebih baik tentang lingkungan sosial di sekitarnya." 
Al Athfaal: Jurnal Ilmiah Pendidikan Anak Usia Dini

"Literasi kritis merupakan kemampuan seseorang dalam memahami teks, yakni dengan cara mengubah perspektif yang biasa digunakan, membaca teks dari berbagai sudut pandang, dan melakukan tindakan akan teks yang sudah dibaca."

"Kemamapuan anak untuk membaca, menulis, behitung supaya anak paham dan lebih baik lagi untuk kehidupan sosialnya kedepan."

"Literasi kritis adalah kemampuan membaca secara aktif, teliti dan pertimbangan yang aktif dalam rangka menggali dan memahami ilmu lebih dalam."

"Merupakan kemampuan yang membantu para pencari informasi dalam memahami teks yang sudah di baca dari berbagai sudut pandang dengan cara perspektif.",

"Merupakan kemampuan yang membantu atau mencari informasi dan memahami apa yang ada di dalam tersebut yakni dengan cara mengubah perspektip yang bisa digunakan contoh memahami sebuah tulisan atau kata-kata."

Tanggapan terhadap pertanyaan ini menunjukkan bahwa semua guru anak usia dini mendefinisikan literasi kritis mirip dengan berpikir kritis, yang hanya berfokus pada bagaimana seseorang dapat membaca dan memahami teks secara aktif dan reflektif. Sebagai contoh, beberapa peserta menyebutkan bahwa literasi kritis berarti kemampuan untuk memahami informasi secara aktif dan reflektif. Para peserta juga menyatakan bahwa literasi kritis adalah kemampuan memahami teks dari perspektif yang berbeda. Beberapa definisi literasi kritis yang dikemukakan peserta di atas, seperti kemampuan membaca secara inaktif dan reflektif dan kemampuan memahami teks dari perspektif yang berbeda mirip dengan definisi berpikir kritis. Ahli-ahli berpikir kritis menyarankan bahwa dalam melakukan berpikir kritis siswa berkomitmen untuk keterampilan yang disebutkan di atas. Namun, dalam pendidikan literasi kritis, tujuannya selangkah lebih maju. Dalam literasi kritis, baik siswa maupun guru yang terlibat harus mulai berpikir dari perspektif kritis secara ekstensif. Misalnya, ketika siswa membaca sesuatu, mereka harus dapat mempertanyakan suara siapa yang terdengar dan suara siapa yang tidak terdengar, mengapa teks ini ditulis dengan cara ini dan siapa yang diuntungkan, bagaimana posisi sosial pembaca dan penulis dalam teks tersebut., dan lain-lain (Lewison et al., 2002).

\section{B. Pembahasan}

Terlepas dari pemahaman dan pengetahuan guru anak usia dini antara literasi kritis dan berpikir kritis, tanggapan lain untuk pertanyaan ini adalah cara guru menghubungkan literasi kritis dengan membaca dan menulis. Hampir semua peserta 
mengaitkan literasi kritis dengan membaca dan menulis. Para peserta menyatakan bahwa literasi kritis adalah kemampuan membaca dan memahami makna teks. Berdasarkan temuan ini, dapat disimpulkan bahwa hampir semua guru anak usia dini yang dipekerjakan dalam penelitian ini masih mendefinisikan literasi sebagai terbatas pada keterampilan membaca dan menulis. Sementara itu, pendidikan literasi kritis sendiri telah mengalami pergerakan yang signifikan dari kemampuan membaca dan menulis (Kalantzis \& Cope, 2012), menuju proses pembelajaran dimana kita belajar bagaimana menciptakan dan memahami makna untuk mengubah dan menantang dunia. Saat ini, kemampuan untuk membuat makna yang tertanam dalam literasi kritis difasilitasi oleh penggunaan mode yang berbeda seperti dari internet, videogame, gambar, grafik, dan tata letak.

Berdasarkan jawaban dari peserta yang telah diuraikan di atas, terlihat bahwa pemahaman guru peserta didik muda tentang literasi kritis masih sangat kurang atau bahkan dapat dikatakan belum mengetahui apa itu literasi kritis. Begitu juga dengan pengetahuan yang mereka miliki tentang literasi kritis. Hal ini terlihat dari jawaban mereka dalam kuisioner online. Dalam menjawab kuesioner online, mereka cenderung dapat mendefinisikan literasi dan kekritisan secara terpisah dalam konteks tradisional. Namun, ketika dihadapkan pada istilah literasi kritis, mereka hanya menjawab dengan definisi gabungan dari dua istilah yang ditanyakan sebelumnya. Mereka juga hanya menurunkan definisi dari istilah "kritis" dan "literasi" tanpa mengetahui esensi literasi kritis yang sebenarnya. Oleh karena itu, tidak satupun dari mereka yang mendekati definisi literasi kritis. Temuan-temuan di atas mungkin saja terjadi karena guru-guru anak usia dini belum familiar dan bahkan belum pernah mendengar apa itu literasi kritis, sehingga mereka masih bingung dengan definisi literasi kritis.

\section{Keyakinan guru anak usia dini tentang implementasi literasi kritis di kelas mereka}

Berbeda dengan jawaban pertanyaan pertama dimana hampir semua responden memiliki gambaran yang kurang meyakinkan tentang apa itu literasi kritis, pada pertanyaan kedua hampir semua peserta percaya bahwa literasi kritis bermanfaat dan dapat diterapkan untuk mengajar anak usia dini. Mereka percaya bahwa penerapan literasi kritis dapat membantu anak usia dini untuk mengembangkan kemampuan membaca, menulis, dan mempersiapkan mereka untuk siap masuk ke tingkat sekolah 
dasar dan menjadi siswa yang kritis. Para guru juga percaya bahwa siswa mereka bisa menjadi pemikir yang lebih baik karena mereka akan belajar bagaimana berpikir kritis.

"Literasi Kritis bermanfaat, karena dalam aspek perkembangan bahasa, saat anak mendengar cerita atau nasehat yang disampaikan guru atau orang yang ada disekitarnya, diharapkan anak bisa mengetahui dan membedakan mana yang baik atau tidak untuk dirinya."

"Memahami atau mengajarkan anak mengenai literasi kritis sangat bermanfaat untuk anak, karena pendidikan literasi kritis dapat melatih kemampuan dasar anak untuk membaca, menulis dan menghitung, mengembangkan kemampuan berpikir kritis."

"Banyak manfaat dari mengajarkan literasi kritis, seperti untuk melatih kemampuam dasar anak membaca, menulis, dan menghitung, mengembangkan kemampuan berfikir-kritis, mempersiakan anak untuk masuk dunia sekolah, perkembangan literasi yang baik berkorelasi dengan prestasi akademik."

"Sangat bermanfaat, karena literasi saja tak cukup untuk bekal hidup anak dimasyarakat diperlukan literasi kritis sehingga anak dapat membendung arus informasi yang sangat deras menyaringnya dengan kritis dan tak terbawa arus."

"Karena agar anak tersebut mempunyai sikap berfikir kritis dan logis dalam menyikapi informasi. Selain itu agar anak mempunyai sikap disiplin, dan juga agar membantu kemampuan dasar anak untuk menulis, membaca dan menghitung."

"Ya sangat bermanfaat sekali karena anak usia dini sangat memerlukan pembelajaran dengan literasi kritis tersebut agar anak bisa berkembang sesuai dengan kemampuannya yang refleks mandiri dan aktif untuk menghadapi kehidupan sosialnya sehari- hari dan masa depannya."

Di sisi lain, beberapa dari mereka masih ragu-ragu dan bahkan belum menemukan manfaat dari penerapan literasi kritis di kelas mereka karena mereka tidak memiliki ide yang jelas tentang bagaimana menerapkan literasi kritis di kelas dan mereka berpikir bahwa literasi kritis tidak tepat untuk diajarkan kepada anak usia dini. Belakangan, mereka juga tidak percaya diri karena takut kepala sekolah tidak mendukung mereka untuk mengadakan kelas berbasis kritis karena kesulitannya. Beberapa dari mereka juga menyatakan bahwa mereka tidak memiliki fasilitas yang memadai untuk memfasilitasi siswa di dalam kelas.

"Mungkin, tapi tidak sampai dasarnya."

"Mungkin saja, bila sudah tahu."

"Memungkinkan, karena paktor perkembangan jaman dalam lingkungan sekolah banyak sekali di temukan siswa dalam minat membaca dan menulis sudah mulai berkurang apalagi pengaruh teknologi di jaman sekarang."

"Menurut saya tidak, karena anak usia dini cara membacanya masih banyak yang belum lancar ada beberapa anak yg belum tau huruf abjad."

"Tidak terlalu, dikarenakan anak usia dini seharus nya pemikiran di sesuiakan dengan umur nya dan pembelajaran usia dini mah bermain sambil belajar, kita sebagai pendidik harus mengeriti akan karakter masing masing anak." 
"Tidak.karenaliterisasi kritis untuk anak yang lebih besar."

Namun, beberapa penelitian membuktikan bahwa penerapan literasi kritis pada anak usia dini dapat mengembangkan kemampuan anak usia dini untuk terlibat dengan semua modalitas teks yang bermanfaat bagi mereka untuk membuat mereka menjadi warga zaman ini. Literasi kritis juga mempersiapkan anak usia dini untuk masa depan mereka dan partisipasi mereka di dunia yang lebih besar di sekitar mereka untuk membawa keadilan sosial. Studi juga telah meruntuhkan asumsi guru anak usia dini di atas tentang ketidakmampuan anak usia dini untuk terlibat dalam pembelajaran berbasis kritis karena, pada kenyataannya, anak usia dini dapat terlibat dalam kelas berbasis kritis (James \& McVay, 2009; Labadie et al., 2012).

\section{SIMPULAN DAN SARAN}

Dari hasil angket terbuka, dapat disimpulkan bahwa sebagian besar guru dalam penelitian ini mungkin belum sepenuhnya memahami esensi literasi kritis. Namun, mereka cenderung mendefinisikan literasi kritis dari cara tradisional masing-masing definisi "kritis" dan "literasi". Selain itu, sebagian besar peserta dalam penelitian ini masih ragu untuk menerapkan literasi kritis di kelas mereka karena mereka tidak memiliki gagasan yang jelas tentang literasi kritis dan kelas berbasis kritis.

Bagi guru yang ingin menerapkan literasi kritis, beberapa ahli di bidang ini telah menggariskan strategi yang dapat digunakan di kelas, terutama dalam konteks EFL. Pertama, guru harus menjadi pembaca kritis untuk membantu siswa menjadi kritis. Kemudian, mereka dapat menerapkan kerangka instruksional lima langkah yang terdiri dari: menjelaskan, mendemonstrasikan, membimbing, mempraktikkan, dan merefleksi.

Pada langkah pertama, guru harus menjelaskan apa itu literasi kritis dan mendemonstrasikan bagaimana mereka dapat menerapkan literasi kritis di kelas. Setelah itu, mereka dapat memulai literasi kritis dengan teks-teks sehari-hari (Lewison et al., 2002) di mana mereka mengarahkan siswa untuk mempertanyakan sesuatu yang dianggap normal di lingkungan mereka. Guru dapat memulai dengan buku teks yang biasa digunakan di sekolah, kemudian memberikan kesempatan kepada siswa untuk mengidentifikasi suara siapa yang terdengar dan suara siapa yang hilang. Selain itu, mereka mungkin juga ingin memasukkan berbagai mode teks di kelas dalam bentuk 
latihan untuk memberikan variasi di dalam kelas sehingga paparan siswa terhadap berbagai jenis teks meningkat. Langkah terakhir adalah melakukan refleksi atas kegiatan yang telah mereka lakukan. Kegiatan tersebut dapat berupa ulasan dan kesimpulan singkat atau dalam bentuk jurnal reflektif.

Karena studi tentang literasi kritis dalam konteks anak usia dini di Indonesia relatif sedikit, studi ini diharapkan dapat memperkuat pengetahuan guru anak usia dini tentang literasi kritis dan implementasinya dalam praktik kelas. Oleh karena itu, untuk penelitian lebih lanjut, studi yang lebih komprehensif dengan melibatkan lebih banyak guru anak usia dini di seluruh wilayah Indonesia akan sangat bermanfaat. Dengan waktu yang lebih lama, diharapkan kita dapat menggali masalah ini lebih dalam dan memperhatikan perubahan dan tantangan yang mungkin dialami para guru di kelas mereka.

Sebagai saran dalam waktu dekat, sosialisasi tentang literasi kritis yang memuat apa itu dan bagaimana penerapannya di kelas sangat dibutuhkan oleh semua guru khususnya guru PIAUD yang merupakan guru awal peserta didik di generasi mendatang. Dengan adanya sosialisasi ini diharapkan guru-guru dapat lebih mengenal dan lebih memahami literasi kritis dan pentingnya mengajarkannya. Akhirnya, saya ingin mendorong para ahli literasi untuk memperkenalkan literasi kritis kepada guru anak usia dini. Dengan perkembangan zaman, teknologi, sosial, dan budaya di Indonesia saat ini, siswa perlu dibekali dengan keterampilan literasi kritis. Namun, tanpa guru kritis melek, tujuan ini mungkin tidak sepenuhnya tercapai.

\section{UCAPAN TERIMA KASIH}

Saya mengucapkan terima kasih kepada semua siswa saya dari Pendidikan Islam Anak Usia Dini (PIAUD) di STAI Siliwangi Garut yang berpartisipasi dalam Penelitian ini. Saya juga mengucapkan terima kasih kepada rekan-rekan dosen yang selalu memberikan semangat dalam membuat penelitian.

\section{DAFTAR PUSTAKA}

Alwasilah. (2001). Language, Culture, and Education . Andira.

Bacon, C. K. (2017). Multilanguage, Multipurpose: A Literature Review, Synthesis, and Framework for Critical Literacies in English Language Teaching. Journal of Literacy Research, 49(3). https://doi.org/10.1177/1086296X17718324 
Coffey. (2010). Critical literacy. Journal of Adolescent and Adult Literacy, 87.

Falkenstein, A. (2003). Critical literacy in an EFL context.

Fisher, R. (2005). Teaching children to think. Nelson Thornes.

Gustine, G. G. (2018). A survey on critical literacy as a pedagogical approach to teaching English in Indonesia. Indonesian Journal of Applied Linguistics, 7(3).

Hidayat, R. A. U. (2020). An Inquiry Study on Teachers' Beliefs and Knowledge of Critical Literacy Pedagogy in Indonesia Context. Twelfth Conference on Applied Linguistics (CONAPLIN 2019).

Hood, S. (1998). Critical literacy: What does it mean in theory and practice. Teachers' Voices, 3.

James, J. H., \& McVay, M. (2009). Critical literacy for young citizens: First graders investigates the first Thanksgiving. Early Childhood Education Journal, 36(4).

Janks, H. (2010). Literacy and power. Routledge.

Kalantzis, M., \& Cope, B. (2012). Literacies. Cambridge University Press.

Kaur, S., \& Sidhu, G. K. (2014). Evaluating the Critical Literacy Practices of Tertiary Students. Procedia - Social and Behavioral Sciences, 123. https://doi.org/10.1016/j.sbspro.2014.01.1396

Koo, Y. L., Wong, F. F., \& Kemboja Ismail. (2012). Students' critical consciousness through critical literacy awareness. Gema Online ${ }^{\circledR}$ Journal of Language Studies, 12(1).

Labadie, M., Wetzel, M. M., \& Rogers, R. (2012). Opening spaces for critical literacy: Introducing books to young readers. The Reading Teacher, 66(2).

Lee, C. J. (2012). From disrupting the commonplace to taking action in literacy education. Journal of Thought, 47(2).

Lewison, M., Flint, A. S., \& van Sluys, K. (2002). Taking on critical literacy: The journey of newcomers and novices. Language Arts, 79(5), 382-392.

Luke, A., \& Woods, A. F. (2009). Critical literacies in schools: A primer. Voices from the Middle, 17(2), 9-18.

McDaniel, C. A. (2006). Critical literacy: A way of thinking, a way of life (P. Lang, Ed.; Vol. 296).

Norris, K., Lucas, L., \& Prudhoe, C. (2012). Examining critical literacy: Preparing preservice teachers to use critical literacy in the early childhood classroom. Multicultural Education, 19(2), 59-62.

Park, J. Y. (2012). A Different Kind of Reading Instruction: Using Visualizing to Bridge Reading Comprehension and Critical Literacy. Journal of Adolescent \& Adult Literacy, 55(7). https://doi.org/10.1002/JAAL.00074

Peterson, K. E., \& Chamberlain, K. (2015). "Everybody Treated Him Like He Was From Another World": Bilingual Fourth Graders Develop Social Awareness Through Interactive Read-Alouds Focused on Critical Literacies. Literacy Research and Instruction, 54(3). https://doi.org/10.1080/19388071.2015.1027020 